\title{
A synthesis of best available evidence and expert opinion on outcomes after cervical trauma: what should surgeons be telling their patients?
}

Authors Peter Lewkonia ${ }^{1}$, Christian P DiPaola ${ }^{2}$, Rowan Schouten ${ }^{1}$, Marcel Dvorak ${ }^{1}$, Charles G Fisher ${ }^{1}$ Institutions ${ }^{1}$ Combined Neurosurgical and Orthopaedic Spine Program, Department of Orthopaedics, University of British Columbia, Vancouver, British Columbia, Canada

${ }^{2}$ Spine Division, Department of Orthopedics, University of Massachusetts Medical Centre, Worcester, MA, USA

Study design: Systematic review and expert opinion.

Background: Patients with cervical spine injuries without neurological deficit form a substantial portion of most spine surgeons' practices. Patients' expectations regarding quality-of-life outcomes are highly dependent on the information provided by surgeons early in the treatment course [1]. Our previous work has demonstrated that there is substantial variability in what surgeons tell patients regarding outcomes of these injuries; thus patient expectations will differ and outcomes vary [2].

Objective: An objective, systematic, evidence-based approach to providing guidelines to patients at the time of injury is needed to reduce variability.

Methods: Five common cervical spine injuries and treatments (Jefferson and Hangman fracture treated nonoperatively, odontoid fracture treated with anterior or posterior fixation, and unilateral facet fracture treated operatively) were considered (Table 1). A systematic review of the available medical literature from 1980 to 2010 was conducted, and combined with expert opinion from a recent survey of spine surgeons who treat traumatic spinal injury. From these two sources, we assessed the evidence regarding five health-related quality-of-life outcomes: time to return to work, activity level, hospital stay, and the proportion of patients who are pain free and have regained full range of motion at 1 year postinjury.

Results: Published outcome data was available for most injuries, especially facet and odontoid fractures. Using consensus expert opinion and the literature, answers to each question were achieved. For example, in Jefferson fractures $35 \%$ of patients experience persistent neck or scalp pain and SF-36 PC scores average ten points lower than normative values. No studies have assessed return to manual or labor work, but expert consensus recommended 5 months. Overall, expert opinion was relatively homogeneous across injury types, suggesting that experts do not distinguish between specific injuries when advising patients of expected outcomes such as pain (Fig 1). 
Table 1 Clinical scenarios.

\begin{tabular}{llllll}
\hline & $\begin{array}{l}\text { Jefferson } \\
\text { fracture }\end{array}$ & $\begin{array}{l}\text { Hangman } \\
\text { fracture }\end{array}$ & $\begin{array}{l}\text { Odontoid } \\
\text { (anterior) }\end{array}$ & $\begin{array}{l}\text { Odontoid } \\
\text { (posterior) }\end{array}$ & $\begin{array}{l}\text { Facet } \\
\text { fracture }\end{array}$ \\
\hline $\begin{array}{l}\text { Clinical description } \\
\text { of injury }\end{array}$ & $\begin{array}{l}\mathrm{Cl} \text { /atlas burst or ring } \\
\text { fracture }\end{array}$ & $\begin{array}{l}\text { Traumatic spondylolisthesis } \\
\text { of C2/axis on C3 }\end{array}$ & $\begin{array}{l}\text { Type II or III } \\
\text { odontoid fracture }\end{array}$ & $\begin{array}{l}\text { Type II or III } \\
\text { odontoid fracture }\end{array}$ & $\begin{array}{l}\text { Unilateral facet fracture with traumatic } \\
\text { spondylolisthesis or dislocation }\end{array}$ \\
\hline Patient description & $\begin{array}{l}\text { 22-year-old male } \\
\text { construction worker }\end{array}$ & 41-year-old woman & $\begin{array}{l}55 \text {-year-old male } \\
\text { executive }\end{array}$ & 70-year-old woman & 36-year-old male teacher \\
\hline Treatment & $\begin{array}{l}\text { Cervical } \\
\text { or cervico-thoracic } \\
\text { orthosis/HTV }\end{array}$ & $\begin{array}{l}\text { Cervical or cervico- } \\
\text { thoracic orthosis/HTV }\end{array}$ & $\begin{array}{l}\text { Anterior screw } \\
\text { fixation }\end{array}$ & $\begin{array}{l}\text { Primary posterior } \\
\text { C1-C2 instrumented } \\
\text { fusion }\end{array}$ & $\begin{array}{l}\text { Either anterior decompression and fusion } \\
\text { or posterior instrumented fusion (with or } \\
\text { without decompression) }\end{array}$ \\
\hline
\end{tabular}

Fig 1 Mean percentage of patients predicted to be pain free at 1 year for each injury and treatment scenario.

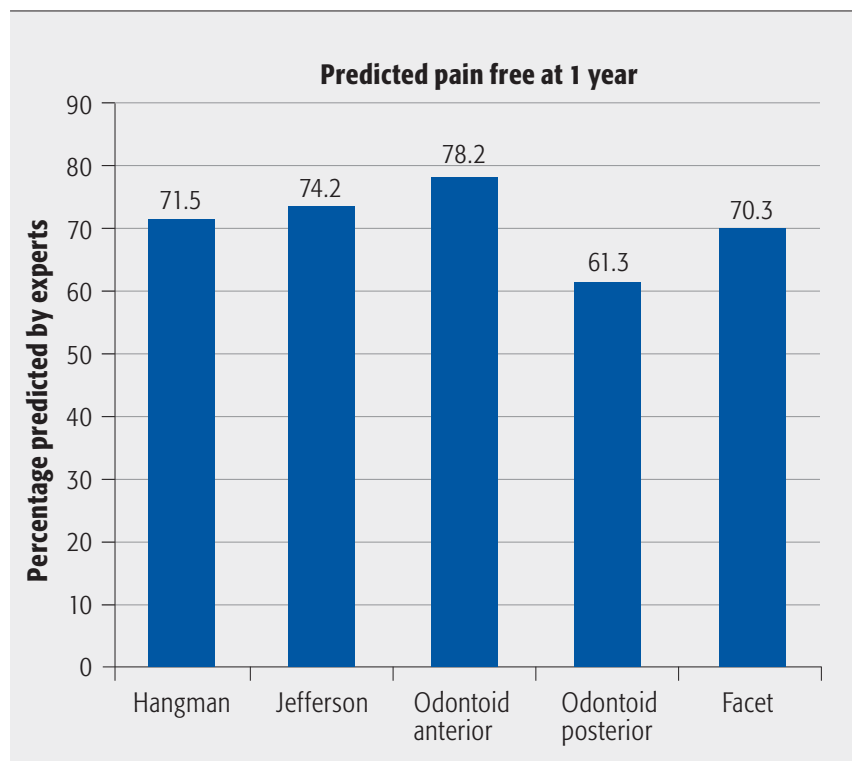

Conclusions: Cervical spine injury may lead to both short- and long-term disability even with optimal treatment. Outcomes have been poorly understood by surgeons and other providers along the care path. This variability in combination with a patient's preconceived notions of a neck injury lead to varied expectations and potentially inferior outcomes. By overcoming gaps in the literature with consensus expert opinion, our study provides surgeons and others with evidencebased medicine guidelines. This information can be presented to patients to frame expectations of typical outcomes during and after treatment.

\section{REFERENCES}

1. Mondloch MV, Cole DC, Frank JW (2001) Does how you do depend on how you think you'll do? A systematic review of the evidence for a relation between patients' recovery expectations and health outcomes. Cmaj. 24;165(2):174-179.

2. Davidson D, Noonan VK, Dvorak MF, Zhang H, Fisher CG (2010) The impact of patient expectations on outcome following treatment for spinal trauma: part 1: what are spine surgeons telling their patients? Spine;35(19):1807-1811. 